\title{
PSZICHOSZOMATIKUS TÜNETEK GYAKORISÁGÁT BEFOLYÁSOLÓ TÉNYEZŐK 18-90 ÉVES NŐK KÖRÉBEN
}

\author{
Fehér Piroska, Annár Dorina, Zsákai Annamária és Bodzsár Éva† \\ Eötvös Loránd Tudományegyetem, Embertani Tanszék, Budapest
}

Fehér P., Annár D., Zsákai A., Bodzsár É.: The determinants of psychosomatic health complaints in 18-90 year-old women. Psychosomatic health complaints are common in children and adults as well, and affect the quality of later life. Age tendency of psychosomatic complaints are influenced by regional, socioeconomic, environmental and lifestyle factors. Our aims were to reveal the age pattern of the psychosomatic health complaints in Hungarian women aged 18-90 years and to identify those components of lifestyle, body structure and environmental factors that affect the pattern of psychosomatic complaints among 18-90 year-old women.

Healthy premenopausal and postmenopausal women were enrolled to the present analysis $(n=483)$. Three groups of the psychosomatic health complaints were used: somatic (abdominal pain, headache, dizziness), psychic (irritability, nervousness, grumpiness) and sleep disorders (awakenings during the night, falling asleep difficulties, waking up tired). Frequency distributions of women experiencing somatic, psychic complaints and sleep disorders often (daily or several times a week) were analysed by comparing the results derived from our previous auxological study. Logistic regression analysis was applied to reveal the relationship between the groups of psychosomatic health complaints and the hypothesized predictive factors.

The frequency of the most psycho-somatic complaints reached maximum values in the age-group of 21-25 years and another increase was identified in women aged 56-60. Irritability, waking up tired and awakenings during the night were the most frequently reported symptoms. The frequency of symptom of awakenings during the night increased up to the age group of 61-65 years. The results of the regression analysis revealed that the frequency of the psychic complaints and the level of physical activity affected the frequency of somatic complaints. Age, sleep disorders and somatic complaints were determinants of the psychic complaints. Postmenopausal status and the frequency of the psychic complaints influenced the frequency of sleep disorders.

Numerous factors of lifestyle and body structure were tested in the analysis. Special life events (school, work, birth of children, menopause) are suspected in the background of the highlighted periods. More factors (socioeconomic status, nutrition, health condition, disabilities) should be considered in future studies.

Keywords: Psychosomatic health complaints; Somatic complaints; Psychic complaints; Sleep complaints; Physical activity; Menopausal status.

\section{Bevezetés}

A pszichoszomatikus tünetek előfordulási gyakorisága gyermek és serdülőkorban nem elhanyagolható. Számos tanulmány megerősítette, hogy a pszichoszomatikus tünetek gyakorisága nő az életkor elörehaladtával és gyakrabban fordul elő a leányoknál, mint a fiúknál (Aro és mtsai 1987, Haugland és mtsai 2001). A pszichoszomatikus tünetek átlagos előfordulási gyakorisága 10-25\% gyermek és serdülőkorúaknál (Brill és mtsai 2001). A tünetek közül a fejfájás és hasfájás fordulnak elő leggyakrabban (Santalahti és mtsai 2005). Egy finn tanulmányban közölt adatok szerint a 14-15 éves serdülők 30\%-nál 
jelentkezett fejfájás hetente egyszer vagy többször. Az Amerikai Egyesült Államokban a serdülők 30,6\%-a számolt be krónikus fáradtságról hetente egyszer vagy többször, ugyanerről Finnországban 38\%-uk panaszkodott. A depressziós tünetek előfordulási gyakorisága

4-10\% között változik a tanulmányok módszertanától függően (Kinnunen 2010).

A pszichoszomatikus tünetek etiológiája multifaktoriális, gyermekeknél és serdülőknél a pszichoszomatikus tünetek kialakulásában a genetikailag determinált hajlamon túl, a szocio-ökonómiai háttér tényezői és az iskolai környezet, mint stresszor is szerepet játszik. Hjern és mtsai (2008) 10-18 éves gyermek körében $(\mathrm{n}=2588)$ végeztek vizsgálatokat, és megállapították, hogy a társak zaklatása, az iskolai terhelés és a pedagógus nem megfelelő bánásmódja összefüggést mutatott mind a pszichoszomatikus tünetekkel, mind az olyan pszichés panaszokkal, mint a szomorúság, ingerlékenység, idegesség és biztonságérzet hiánya. További potenciális stresszforrást jelenthet a gyermekeknél és serdülőknél a családi problémák, társak nyomása, krónikus betegségek megléte, költözés, a szülők cselekvőképtelensége, szülők pszichiátriai betegsége, sikertelen megküzdési stratégiák (Brill és mtsai 2001).

A gyermekkori egészségi állapot hatással van a későbbi életévek minőségére is. Pikó és munkatársai (1997) egészséges 18-31 éves magyar egyetemista hallgatók körében vizsgálták a pszichoszomatikus tünetek gyakoriságát. Azt tapasztalták, hogy a leggyakrabban előforduló tünet a hátfájás, alvászavarok, krónikus fáradtság volt férfiaknál, krónikus fáradtság, hátfájás, tenziós fejfájás, alvászavarok nőknél. Kinunnen és munkatársai (2010) összefüggést találtak a serdülőkori pszichoszomatikus tünetek gyakorisága és a felnőttkorban jelentkező mentális betegségek, a depresszió és szorongás között.

Korábbi tanulmányunkban a pszichoszomatikus tünetek előfordulási gyakoriságát vizsgáltuk gyermekek és serdülökorúak körében (Fehér és mtsai 2019). A gyermek és serdülőkorú, illetve posztpubertáskorú leányok és fiúk almintája a Második Országos Növekedésvizsgálat mintájából került kiválasztásra (Bodzsár és Zsákai 2012). Az országos reprezentatív növekedésvizsgálat során a 3-18 éves $(n=25151)$ magyar gyermekek testfejlettségi és tápláltsági állapotának, pszichoszociális és mentális egészségi státuszának, illetve a gyermekek életmódját jellemző tényezőknek (táplálkozási szokásaik, fizikai aktivitásuk tényezői) felmérése került sor (Bodzsár és Zsákai 2012). Az elemzéshez 6680 8-17 év közötti fiú és 6651 leány adatait használtuk fel. Az egyes pszichoszomatikus tünetek gyakorisága kérdőív segítségével került felmérésre, amelyet személyes interjúk egészítettek ki. Az egyes pszichoszomatikus tüneteket tünetcsoportokba soroltuk. A testi tünetek közé a fejfájás, a hasfájás és a szédülés tartozott, a pszichés tünetek csoportjába a rosszkedvüség, az ingerlékenység és az idegesség került, míg az alvási nehézségek csoportjába soroltuk, ha a gyermek nehezen tud elaludni, gyakran felébred éjjel, és fáradtan ébred (elegendő mennyiségü alvást követően is). A Haugland-féle módszernek megfelelően az egyes pszichoszomatikus tünetek és a három tünetcsoport (testi, ill. pszichés tünetek, alvási nehézségek) esetén is a panaszokat gyakran (naponta vagy hetente többször), átlagos gyakoriságban (hetente) és ritkán (havonta vagy soha) átélők csoportjait alakítottuk ki, de az ábrákon csak a panaszokat gyakran átélők gyakoriságát tüntettük fel (Haugland és mtsai 2001). A pszichoszomatikus tünetek életkori mintázatának vizsgálatához három életkori csoportot különítettünk el. Az első korcsoportba a 8-10 éveseket, a második korcsoportba a 11-14 éveseket, a harmadik korcsoportba a 15-17 éveseket soroltuk. 
Vizsgálati eredményeink közül most csak a leányokra vonatkozókat említjük meg. A szomatikus tüneteket gyakran átélő leányok gyakorisága a szédülés és a hasfájás esetében a $15 \%$-os, míg fejfájás esetében a több, mint 25\%-os gyakoriságot is elérte a vizsgált korintervallum végére. A pszichés tünetek közül a leányok esetében az ingerlékenységet gyakran átélők gyakorisága az életkor előrehaladtával fokozatosan nőtt a 25-30\%-os gyakoriság eléréséig. A rosszkedvüség tünete a leányok esetében a 30\%-os gyakoriságot is elérte a posztpubertáskorú leányok korcsoportjában. Az idegesség tünetét gyakran átélö leányok gyakorisága 40-45\%-ig fokozódott a harmadik korcsoportban. Az elalvási nehézség és gyakori éjszakai felébredés tünetét gyakran átélő leányok gyakorisága a harmadik korcsoportban elérte a 20\%-os gyakoriságot. A fáradtan ébredés tünetére gyakran panaszkodó leányok gyakorisága 45\%-ig fokozódott a vizsgált korintervallum végére (Fehér és mtsai 2019).

„A reprodukciós öregedést kísérő testszerkezeti változások változókorú nőkben” című, OTKA (K83966) vizsgálat keretein belül 2012-2014 között 35 éves kor feletti nőktől ( $n=1747)$ történt kérdőíves adatgyüjtés a menstruációs és reproduktív történetük jellemzőire, egészségi állapotukra, pszicho-szomatikus státuszukra, életmódjukra (habituális fizikai aktivitásuk és táplálkozásuk szokásaira), valamint szubjektív jóllétérzetükre vonatkozóan. A menstruációs ciklusok rendszertelenné válásának kora (átlag értéke: 48,3 év) kb. 3 évvel megelőzte a menopauzakort (átlag értéke: 51,35 év) a magyar nők körében. A menopauzát megelőző években a női nemi hormonok szintje csökken, mely jellegzetes tünetek (perimenopauzális tünetek) megjelenéséhez vezet. Ide sorolhatók az olyan vazomotoros tünetek, mint a hőhullámok, izzadás, kipirulás, a szöveti atrófiát kísérő tünetek (inkontinencia, bőrszárazság), illetve gyakrabban fordulnak elő és intenzívebben jelentkeznek az olyan pszichoszomatikus tünetek, mint a fejfájás, ingerlékenység, hasfájás, szédülés, depresszió, szorongás, szédülés. A vizsgálat eredményei szerint a változókorú nők leggyakrabban a haspuffadásra (33\%-uk), a hőhullámokra (19\%-uk), egyedüllét iránti vágyódásra (19\%-uk) és a pánikra és félelemre, ill. éjszakai gyakori izzadásra (14\%-uk) panaszkodtak. A pszichoszomatikus tünetek előfordulási gyakorisága kisebb volt a premenopauzális státuszú nők csoportjában, mint a peri, illetve posztmenopauzális státuszú nők csoportjában (Zsákai és mtsai 2016).

Bemutatásra kerülő elemzésünkben gyermekektől és serdülőktől 2003-2006 között, általunk gyüjtött adatokat hasonlítunk össze felnőttektől és időskorúaktól 2016-2019 között gyüjtött adatokkal, hogy a pszichoszomatikus tünetek gyakoriságának életkori alakulását meg tudjuk vizsgálni. Jelen tanulmányunkban célunk megvizsgálni nők körében: (1) hogyan alakul a pszichoszomatikus tünetek gyakorisága az életkor előrehaladtával felnőttkorban, illetve időskorban, (2) vannak-e a tünetek gyakorisága szempontjából kitűntetett jelentőségü életszakaszok, (3) milyen életmódbeli, testszerkezeti, környezeti tényezők befolyásolják a pszichoszomatikus tünetek gyakoriságát.

\section{Vizsgált személyek és alkalmazott módszerek}

Tanulmányunkban 18-90 év közötti nőknél (n=483) a pszichoszomatikus tünetek elfordulási gyakoriságát kérdőív segítségével mértük fel. A testszerkezet tényezői közül a testösszetevő komponensek mennyiségét bőrellenállás mérésén alapuló Inbody 720 típusú müszerrel (zsírtömeg, kg; vázizom-tömeg, kg; fittségi pontszám), illetve a DrinkwaterRoss-féle (1980) négykomponensű módszer (csonttömeg, kg) segítségével becsültük. A 
csontozat általános állapotát, szerkezetét egy DTU-one ultrahangos oszteométerrel vizsgáltuk (ultrahang frekvenciafüggő csillapodása, BUA, $\mathrm{dB} / \mathrm{MHz}$ ), ultrahang sebessége, $\mathrm{SOS}, \mathrm{m} / \mathrm{s}$ ). Az elemzés során csak azoknak a nőknek az adatait használtuk fel, akiknél a menopauza természetes úton következett be, nem szedtek fogamzásgátlót és egyéb női nemi hormont tartalmazó készítményeket, nem estek át a belső nő nemi szervek eltávolításával járó nőgyógyászati beavatkozáson. Posztmenopauzális státuszúnak tekintettük azokat a nőket, akiknél az utolsó menstruáció időpontját 12 hónapon belül nem követte újabb vérzés. A vizsgálatban való részvétel önkéntes volt, a résztvevők aláírásukkal hozzájárultak az adatok anonim felvételéhez és feldolgozásához. Ugyanazt a kérdőívet alkalmaztuk, mint amit a gyermekek és serdülökorúak körében 2003-2006 között használtunk.

A gyermekek és serdülökorúak vizsgálatához hasonlóan az egyes pszichoszomatikus tüneteket tünetcsoportokba soroltuk. A testi tünetek közé a fejfájást, a hasfájást és a szédülést soroltuk, a pszichés tünetek csoportjába a rosszkedvüség, az ingerlékenység és az idegesség került, míg az alvási nehézségek csoportjába az elalvási nehézséget, a gyakori éjszakai felébredést, és fáradtan ébredés (elegendő mennyiségü alvást követő) tünetét vettük. A Haugland-féle módszer szerint az egyes pszichoszomatikus tünetek és a három tünetcsoport (testi, ill. pszichés tünetek, alvási nehézségek) esetén is a panaszokat gyakran (naponta vagy hetente többször), átlagos gyakoriságban (hetente) és ritkán (havonta vagy soha) átélök csoportjait hoztuk létre (Haugland és mtsai 2001). A felnőtt nők csoportjában 11 életkori korcsoportot alakítottunk ki (1. táblázat). A statisztikai értékelést SPSS 26.0 program segítségével végeztük.

1. táblázat. A vizsgált minta életkor szerinti megoszlása

Table 1. The distribution of the studied sample by age

\begin{tabular}{cc}
\hline Korcsoport (év) - Age-group (years) & $\mathrm{n}$ \\
\hline $18-20$ & 16 \\
$21-25$ & 87 \\
$26-30$ & 38 \\
$31-35$ & 23 \\
$36-40$ & 45 \\
$41-45$ & 64 \\
$46-50$ & 53 \\
$51-55$ & 49 \\
$56-60$ & 33 \\
$61-65$ & 37 \\
$65+$ & 38 \\
Összesen - Together & 483 \\
\hline
\end{tabular}

\section{Vizsgálati eredmények és megvitatásuk}

A pszichoszomatikus tünetek életkori mintázata

A testi tünetek közül a fejfájást, hasfájást és szédülést ábrázoltuk az életkor mentén (1. ábra). 17 éves korig a gyermekek és serdülökorúak vizsgálatából származó adatok szerepelnek (ezeket az eredményeket az ábrákon szaggatott vonallal jelöltük), 18 éves kortól kezdve a 2016-2019 között vizsgált nőktől származó adatok szerepelnek. A 
fejfájás tünete esetén a gyermekkortól kezdve 17 éves korig folyamatosan nő a fejfájás tünetét gyakran átélő leányok gyakorisága. A fejfájást gyakran átélő nők gyakorisági értékeinek csúcspontja 18-20 éves korra tehetö (31,3\%). Az idősebb korcsoportokban egyértelmű tendencia nem figyelhető meg a fejfájás tünetét illetően, egy kiugró értéket $(27,3 \%)$ leszámítva, amely az 56-60 éves nők korcsoportjában figyelhető meg. A hasfájás esetén megállapíthatjuk, hogy a gyermekek körében 12 éves kor körül a legnagyobb $(18,8 \%)$ a tüneteket gyakran átélők gyakorisága, tetőpontját a 21-25 éves korcsoportban éri el $(24,1 \%)$. Az életkorral a hasfájás tünetét gyakran átélők gyakorisága csökken, és csak időskorban mutat újra emelkedést gyakorisága. A szédülés tünetét gyakran átélő nők gyakorisága 17 éves korig nő az életkor előrehaladtával, csúcspontját a 21-25 éves korcsoportban éri el (19,5\%). Az ezt követő korcsoportokban váltakozó tendenciát mutat a szédülést gyakran átélö nők gyakorisága (3-16\% között alakul). A szédülést gyakran átélő nők gyakorisági értékeiben egy kisebb csúcs mutatható ki az 56-60 évesek korcsoportjában $(15,2 \%)$.

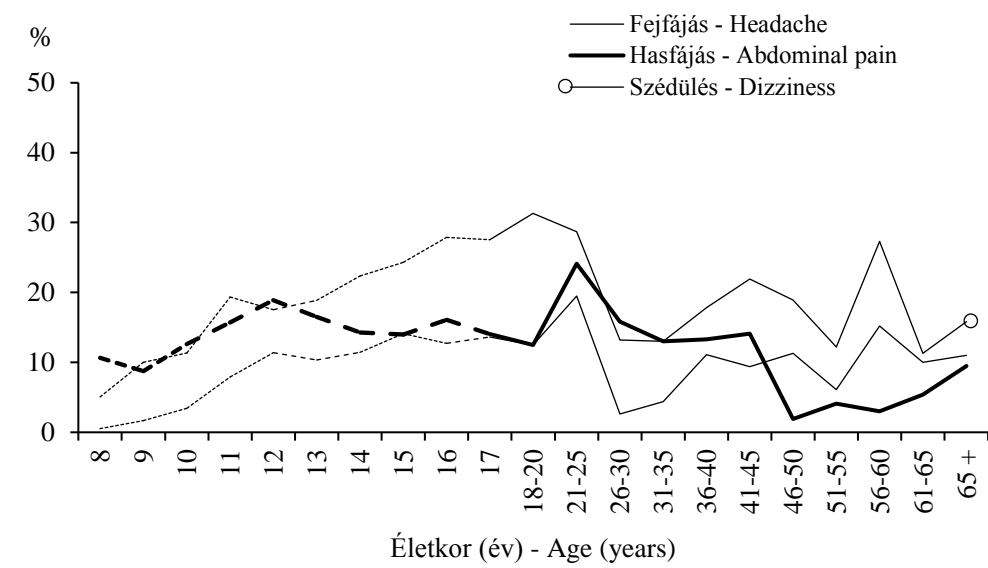

1. ábra: Testi pszichoszomatikus tüneteket (fejfájás, hasfájás, szédülés) gyakran átélő nők relatív gyakoriságának életkori mintázata

Fig. 1: The frequency of women (\%) experiencing often (weekly or more often) somatic complaints (headache, abdominal pain, dizziness)

A pszichés tünetek csoportjába az ingerlékenység, idegesség és rosszkedvüség tünetét soroltuk (2. ábra). E három tünetet gyakran átélő leányok gyakorisága már 8 éves korban 5-15\% között alakul, 17 éves korra az idegesség esetén a 40\%-os gyakorisági értéket is meghaladta (43,6\%), ingerlékenység esetén a 28,1\%-ot, rosszkedvüség esetén a 31,6\%-ot érte el. Az idegesség tünetét gyakran átélő nők gyakorisági értéke a 21-15 éves korcsoportban érte el a maximumát (56,3\%). Innentől csökkenő-növekvő szakaszok jellemzik az idegesség tünetét gyakran átélő nők gyakorisági értékeit. Az 56-60 éves nők korosztályában a gyakorisági értékeket tekintve egy kisebb csúcspont igazolható (39,4\%). $\mathrm{Az}$ ingerlékenység és rosszkedvüség a leányok és nők körében feltünően hasonló tendenciát mutat. A gyermekkor és serdülőkor során nő az e két tünetet gyakran átélő leányok gyakorisága, maximális értékét az ingerlékenység esetén a 21-25 éves 
korosztályban éri el $(43,7 \%)$, a rosszkedvüség esetén a 18-20 éves korosztályban eléri a 43,8\%-ot, a 26-30 évesek korcsportjában 42,1\%-ot. Az idősebb korcsoportokban váltakozó tendenciát mutatnak az ingerlékenység és rosszkedvüség tünetét gyakran átélő nők gyakorisági értékei. Feltűnő az 51-55 évesek korcsoportjában látható, várakozással ellentétes minimum érték, az ingerlékenység esetén 20,4\%-ra, a rosszkedvüség esetén 14,3\%-ra csökken a két tünetet gyakran átélő nők gyakorisága. Szembetünő azonban, hogy az idősek korcsoportjában ismét $25 \%$ fölé emelkedik az e három tünetet gyakran átélő nők gyakorisága.

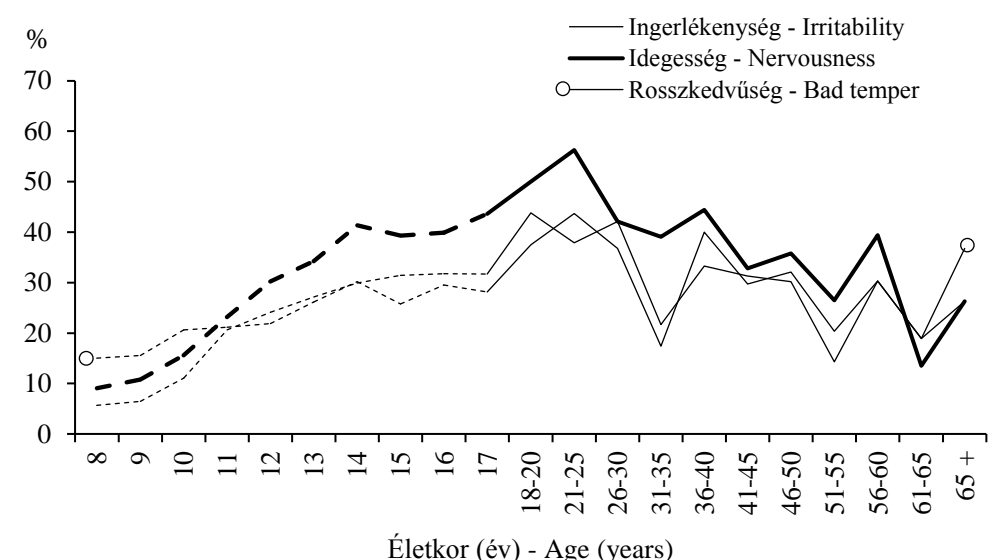

2. ábra: Pszichés pszichoszomatikus tüneteket (ingerlékenység, idegesség, rosszkedvüség) gyakran átélő nők relatív gyakoriságának életkori mintázata

Fig. 2: The frequency of women (\%) experiencing often (weekly or more often) psychic complaints (irritability, nervousness, bad temper)

Az alvási nehézségek tünetcsoportja magába foglalta az elalvási nehézség, a gyakori éjszakai felébredés és fáradtan ébredés tünetét (3. ábra). A fáradtan ébredés tünete meredeken emelkedik a gyermekkor és serdülőkor folyamán, a fáradtan ébredés tünetét gyakran tapasztaló nők gyakorisága a 18-20 évesek korcsoportjában $(56,3 \%)$ éri el maximális értékét, és a 36-40 évesek korcsoportjáig $(51,1 \%)$ alig csökken. Innentől csökkenő tendenciát mutat, az 51-55 évesek korcsoportjában 22,4\%-os gyakoriságig csökken, majd az 56-60 éves korosztályban ismét felemelkedik 39,4\%-ra, ezután már csak időskorban emelkedik meg újra. Az elalvási nehézség és gyakori éjszakai felébredés tünetét gyakran átélő leányok és nők gyakorisági mintázata a 18-20 évesek korcsoportjáig hasonló tendenciát és hasonló gyakorisági értékeket mutat, ezután a két tünetet átélő nők gyakorisági mintázata eltérő tendenciát mutat. Az elalvási nehézséget gyakran átélő nők gyakorisága a 31-35 éves nők korcsoportjában éri el első maximális értékét (43,5\%), majd a 61-65 évesek korcsoportjában mutat még egy csúcsot (37,8\%). A gyakori éjszakai felébredést gyakran tapasztaló nők gyakorisága azonban gyermekkortól kezdve egy-két kisebb kiugró értéket leszámítva (18-20 évesek és 31-35 évesek korcsoportjában) folyamatosan növekszik a 61-65 évesek korcsoportjáig, ahol eléri maximális értékét (59,5\%-ot). Ezután gyakorisága meredeken csökken. 
A pszichoszomatikus tünetek - életmód tényezöi és a testszerkezet mutatói

A pszichoszomatikus tünetek gyakoriságát, intenzitását környezeti, életmódbeli (táplálkozás, fizikai aktivitás mértéke) és testszerkezeti tényezők befolyásolják. Korábbi tanulmányunk (Fehér és mtsai 2019) eredményei szerint 8-17 éves leányoknál a testi tünetek (fejfájás, hasfájás, szédülés) gyakoriságával a testmagasság, tápláltsági állapot testkép és iskolai teljesítmény mutatott szoros összefüggést ( $\chi^{2}$ négyzet próba, $\mathrm{p}=0,002$ ). Leányoknál a nagyobb testmagasság, az alultáplált tápláltsági állapot, a jó tanulmányi eredmény és pozitív testkép csökkentette a testi tünetek gyakoriságát. A pszichés panaszok (ingerlékenység, idegesség, rosszkedvűség) gyakoriságával a leányoknál a szubjektív egészségi állapot, tápláltsági állapot, testkép, teljes énkép és az iskolai tanulmányi eredmény mutatott szignifikáns kapcsolatot ( $\chi^{2}$ négyzet próba, $\left.\mathrm{p}<0,001\right)$. A rossz szubjektív egészségi állapotú, nem alultáplált tápláltsági állapotú, negatív testképü, negatív teljes énképü, rossz tanulmányi eredményủ leányok körében a vizsgált pszichés panaszokat gyakran átélők gyakorisága nagyobb volt, mint a nem ezekbe a kategóriákba sorolható társaik körében. Leányoknál az alvási nehézségek (fáradtan ébredés, gyakori éjszakai felébredés, elalvási nehézség) gyakoriságával csak a lakóhely gazdaságitársadalmi besorolása mutatott kapcsolatot, a hátrányos helyzetü kistérségeken élő leányok gyakrabban éltek át alvási nehézségeket, mint a nem hátrányos helyzetủ településen élő társaik $\left(\chi^{2}\right.$ próba, $\mathrm{p}=0,011$ ).

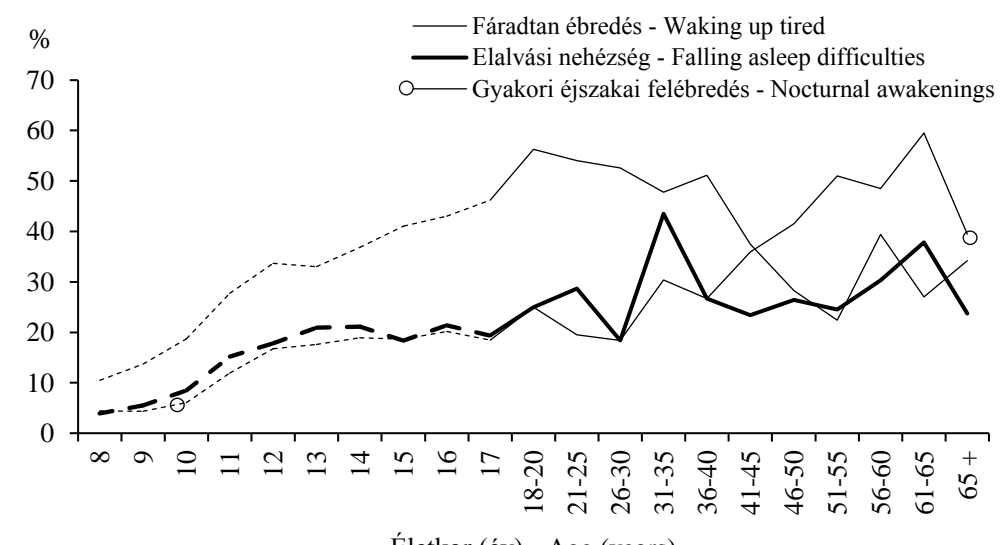

3. ábra: Alvási nehézségeket (fáradtan ébredés, elalvási nehézség, gyakori éjszakai felébredés) gyakran átélő nők relatív gyakoriságának életkori mintázata

Fig. 3: The frequency of women (\%) experiencing often (weekly or more often) sleep disorders (waking up in the morning feeling tired, falling asleep difficulties, nocturnal awakenings)

Célunk volt megvizsgálni, hogy az egyes tünetcsoportok gyakoriságára milyen tényezők gyakorolnak hatást 18-87 éves nők mintáján. Az egyes tünetcsoportok esetén létrehoztunk új változókat („testi tünetcsoport”, „pszichés tünetcsoport” és „alvási nehézségek tünetcsoport"), amely változókat a tünetcsoportba tartozó pszichoszomatikus tünetek gyakorisági értékeiből számoltuk, olyan módon, hogy ha a testi tünetcsoportba tartozó három tünetből legalább kettő gyakori volt, akkor a testi tünetcsoport is gyakori előfordulásúnak számított. 
A feltételezett befolyásoló tényezők közé választottuk a létrehozott tünetcsoport együtteseket, az életkort (év), tápláltsági állapotot (a testtömeg index WHO által meghatározott határértékei alapján: alultáplált, normál, túlsúlyos és obez tápláltsági állapot kategóriák), fittségi pontszámot, dohányzási szokások (dohányzó / nem dohányzó kategóriák), menopauzális státusz (premenopauzális / posztmenopauzális), fizikai aktivitás szintje (a sportolással töltött idő ismeretében aktivitási kategóriákat hoztunk létre, a heti 2 óra vagy annál kevesebb fizikai aktivitást végzőket, a WHO ajánlását teljesítők (18-64 év közötti felnőttek esetén legalább 150 perc mérsékelt intenzitású fizikai aktivitás vagy 75 perc intenzív fizikai aktivitás vagy ezek kombinációja, amely tovább növelhetö heti 300 perc mérsékelt intenzitású vagy 150 perc intenzív fizikai aktivitásig vagy ezek kombinációjáig), illetve az ajánlást meghaladó fizikai aktivitást végzők csoportját (több mint heti 6 órát sportolók). A logisztikus regresszió elemzés során hipotéziseinket 5\%-os szignifikancia szinten teszteltük. A vizsgált tényezők regressziós együtthatójából (B) számolt ún. esélyhányados (exp(B)) megmutatja, hogy folytonos eloszlású magyarázó változó esetén egy egységnyi változása hányszorosára növeli a becsült esemény (gyakori pszichoszomatikus tünetcsoport) bekövetkeztének valószínüségét, illetve diszkrét eloszlású magyarázó változó esetén a vizsgált kategória esetében hányszorosa a becsült esemény bekövetkeztének valószínűsége a referenciakategóriához képest.

Elemzésünk eredményei alapján fittségi pontszámot, megállapítást nyert, hogy a pszichés tünetcsoport tüneteinek gyakori átélése és az ajánlott mértékủ fizikai aktivitást meghaladó mértékủ fizikai aktivitás növelte a testi tünetek gyakoriságát (Omnibusz teszt: $\mathrm{p}=0,044,2$. táblázat).

2. táblázat. A testi, pszichés, ill. alvási nehézségek tünetcsoportok gyakorisága és a befolyásoló tényezőik közötti kapcsolat logisztikus regresszióval történt elemzésének paraméterei

(B: regressziós együttható, $\exp (\mathrm{B})$ : esélyhányados, p: Wald statisztika - szignifikancia szint)

Table 2. The statistical parameters of the logistic regression analysis between the influencing factors and the frequency of somatic complaints, psychic complaints and sleep disorders (B: regression coefficient, $\exp (B)$ : odds ratio, p: level of significance - Wald statistic)

\begin{tabular}{|c|c|c|c|}
\hline & B & $\exp (B)$ & $\mathrm{p}$ \\
\hline $\begin{array}{l}\text { Testi tünetcsoport befolyásoló tényezői- } \\
\text { Factors affecting somatic complaints }\end{array}$ & & & \\
\hline Pszichés tünetek - Psychic complaints & 0,895 & 2,448 & 0,013 \\
\hline $\begin{array}{l}\text { Fizikai aktivitási szint: átlagos aktivitást meghaladó - } \\
\text { The level of physical activity: higher than the average level }\end{array}$ & 1,054 & 2,869 & 0,041 \\
\hline $\begin{array}{l}\text { Pszichés tünetcsoport befolyásoló tényezői- } \\
\text { Factors affecting psychic complaints }\end{array}$ & & & \\
\hline Életkor (év) - Age (years) & $-0,026$ & 0,974 & 0,049 \\
\hline Alvási nehézség tünetcsoport - Sleep disorders & 1,369 & 3,931 & $<0,001$ \\
\hline Testi tünetcsoport - Somatic complaints & 0,882 & 2,416 & 0,025 \\
\hline $\begin{array}{l}\text { Alvási nehézség tünetcsoport befolyásoló tényezöi- } \\
\text { Factors affecting sleep disorders }\end{array}$ & & & \\
\hline $\begin{array}{l}\text { Menopauzális státusz: posztmenopauzális státusz - } \\
\text { Menopausal status - postmenopausal status }\end{array}$ & 0,801 & 2,227 & 0,046 \\
\hline Pszichés tünetcsoport - Psychic complaints & 1,369 & 3,933 & $<0,001$ \\
\hline
\end{tabular}


A logisztikus regresszió elemzés alapján megállapítást nyert, hogy a pszichés tünetcsoport gyakoriságával az életkor, az alvási nehézség tünetcsoport és a testi tünetcsoport mutatott szignifikáns kapcsolatot (Omnibusz teszt: p<0,001). Az életkor csökkentette, a testi és alvási nehézség tünetcsoportba tartozó tünetek gyakori átélése növelte a pszichés tünetek gyakoriságát. Az alvási nehézségek tünetcsoport gyakorisága a posztmenopauzális státusszal mutatott szoros összefüggést és a pszichés tünetcsoporttal szignifikáns kapcsolatban állt (Omnibusz teszt: p<0,001). A posztmenopauzális státusz és a pszichés tünetcsoportba tartozó tünetek gyakori átélése fokozza az alvási nehézségek gyakoriságát (2. táblázat).

\section{Következtetések}

„A reprodukciós öregedést kísérő testszerkezeti változások változókorú nőkben” címü vizsgálat eredményei (Zsákai és mtsai 2015) szerint a fejfájást a premenopauzális státuszú nők (PR) 25,3\%-a, a perimenopauzális (PE) 19\%-a, a posztmenopauzális (PO) státuszú nők 13,7\%-a élte át. A szédülés tünetére a PR státuszú nők 8,5\%-a, PE státuszú nők 9,5\%-a, míg a PO státuszú nők 14,3\%-a panaszkodott. A pszichés tünetek közül az idegesség tünetét kiemelve a PR státuszú nők 15,3\%-a, PE státuszú nők 14\%-a, PO státuszú nők 13,6\%-a élte át. Alvási nehézségek a PR státuszú nők 11,9\%-nál, PE státuszú nők 23,8\%-nál és PO státuszú nők 29,7\%-nál fordultak elő. Általánosságban elmondhatjuk, hogy nagyságrendileg hasonló értékeket kaptunk, különösen a testi tüneteket illetően, de vizsgálatunkban nagyobb volt a pszichés tüneteket (idegesség, ingerlékenység) és alvási nehézségeket gyakran átélő nők gyakorisága.

Bardel és munkatársai (2009) vizsgálatában 35-64 éves svéd nőktől ( $\mathrm{n}=2991)$ gyüjtöttek adatokat az egészségi állapotukra és életminőségükre vonatkozóan. A leggyakoribb tünetek a fáradtság (64,2\%), fejfájás $(54,9 \%)$ rosszkedvüség $(53,7 \%)$, ingerlékenység $(48,1 \%)$ és hátfájás $(47,1 \%)$ volt. A vizsgálatban részvevőknél öt tünet gyakorisága (álmatlanság, láb fájdalom, ízületi fájdalom, látás problémák, hallás gyengülése) nőtt szignifikánsan az életkorral. A fáradtság, fejfájás, ingerlékenység, rosszkedvüség, hátfájás, kimerültség, fázékonyság, sírásra való hajlam, hasfájás, szédülés és hányinger szignifikánsan csökkent az életkorral. Néhány tünet (pl. nyugtalanság, mellkasi fájdalom, idegesség, étvágytalanság) előfordulási gyakorisága nem változott az életkor előrehaladtával. Összehasonlítva a vizsgálati eredményeinkkel azt látjuk, hogy a testi tünetek közül a hasfájást gyakran átélő nők előfordulási gyakorisága 35 éves kor után csökken az életkor előrehaladtával. A fejfájás és szédülést gyakran átélő nők gyakorisági értékei nem mutatnak egyértelmü életkori tendenciát, 56-60 éves korban jelentősen megemelkednek. Az ingerlékenységet, rosszkedvüséget és idegességet gyakran átélő nők gyakorisági értékei sem mutatnak egyértelmü tendenciát 35 éves kor után, míg az álmatlanság egyik tényezőjére, a gyakori éjszakai felébredésre gyakran panaszkodó nők gyakorisági értékei 61-65 évesek korcsoportjában érték el a maximum értéküket, az elalvási nehézséget gyakran átélö nők gyakorisági értékei a 31-35 évesek és a 61-65 évesek korcsoportjában a legnagyobb.

Egy finn nők körében (45-64 évesek, n=1427) végzett tanulmány (Moilanen és mtsai 2010) a menopauzális tünetek előfordulási gyakoriságát és a tünetek gyakoriságának kapcsolatát vizsgálta az életmód tényezőivel (fizikai aktivitás, dohányzás, alkoholfogyasztás). A premenopauzális státuszú nők 38\%-a, a perimenopauzális státuszú nők 50\%-a és a posztmenopauzális és méheltávolításon átesett nők 54\%-a számolt be 
kellemetlen tünetekröl. A rendszeres fizikai aktivitást végző nők kevesebb tünetet tapasztaltak, mint az ülő életmódot folytató nők. Vizsgálatunkban az alvási nehézségek tünetcsoport gyakoriságát növelte a posztmenopauzális státusz és a pszichés tünetcsoport tüneteinek gyakori átélése.

A pszichoszomatikus tünetek előfordulási gyakorisága szempontjából két kitüntetett életkori szakasz a 21-25 éves és az 56-60 éves életkor. Azért, hogy magyarázatot találjunk e két életkori szakasz kiemelt jelentöségére a pszichoszomatikus tünetek gyakoriságát illetően, figyelembe vettük az adott életkori szakaszra jellemző legfontosabb szocio-ökonómiai, fizikai és pszichés változásokat.

2018/2019-es adatok szerint 200,1 ezer magyar fiatal tanul felsőoktatásban, így, ha a pszichoszomatikus tüneteket a stressz egy „biomarkerének” tekintjük, úgy az iskola (egyetem/föiskola) mint stresszor szerepe a 18-25 éves korosztályban is számottevő (KSH 2019). Az iskola szerepét töltheti be később az aktív munkával töltött évek alatt a munkahely. Az alvászavarok előfordulása gyakori az egyetemi hallgatóknál. Schlarb és munkatársai (2017) 2443 német egyetemistát kérdeztek meg az egészségi állapotukról és alvásminőségükről. Vizsgálati eredményeik szerint az egyetemisták 36,9\% számolt be rossz alvásminőségről, 23,5\%-nál ún. szomatoform szindrómát állapítottak meg, és 12,8\%-nál fordult elő valamilyen funkcionális testi tünetegyüttes. Mérsékelt korrelációt mutattak ki a stressz, szorongás, szomatoform szindróma, depresszió és az alvásminőség között. A testi tünetek alvásminőségre gyakorolt hatása összefüggést mutatott a depresszió súlyosságával.

A menopauza egy bio-pszicho-szocio-kulturális aspektusú esemény, amit a nők jelentős része nemcsak a hormonális változásokat kísérő fizikai tünetekkel társít, hanem olyan pszichés változásokkal, mint az önértékelés változása (külső tulajdonságok megváltozása, félelem a magánytól, aggodalom a nőiesség elvesztése miatt) és társadalmi szerepeket érintő változások (gyermekek függetlenedése, nyugdíjazás). A nők által tapasztalt, menopauzához köthető pszichoszomatikus tünetek előfordulási gyakorisága, átélésének intenzitása kulturális különbségeket mutat, befolyásolja az általános egészségi állapot, a fizikai aktivitás mértéke, az életmód tényezői (alkoholfogyasztás mértéke, dohányzás), a szocio-ökonómiai státusz tényezői és a demográfiai mutatók alakulása. Fejlődő országokban élő nőknél előbb következik be a menopauza, szemben a fejlett országokban élő nőknél (Gharaibeh és mtsai 2010).

Vizsgálati eredményeink szerint a pszichoszomatikus tüneteket gyakran átélő nők az 56-60 éves korcsoportba tartoztak, menopauzális státuszukat tekintve inkább a posztmenopauzális csoportba sorolhatók, így elképzelhető, hogy esetükben nem is feltétlenül a menopauza körüli fizikai tüneteknek, hanem sokkal inkább az azt követö évek pszichés változásainak köszönhető a pszichoszomatikus tünetek nagyobb gyakorisága. Az első gyermek vállalásának ideje Magyarországon 28,2 év volt 2013-ban (Monostori és mtsai 2015), így az első unokák születésének az ideje már nem minden esetben a menopauza idejére korlátozódik, hanem inkább 5-6 évvel későbbre tolódik. Ha nem is a család bővülését, de az új élethelyzetet (aggódás, féltés) stresszként élhetik meg a nők. Magyarországon az 1990-es évek elején az általános öregségi nyugdíjkorhatár a férfiak esetében 60 éves, a nök esetén 55 éves kor volt. 1997 és 2009 között nyugdíjkorhatár is emelkedett Magyarországon, amely szerint az 1957-ben vagy azután születettek 65 éves koruktól vehetik igénybe az öregségi nyugdíjellátást (az 1957-ben születettek elörehozott nyugdíjkorhatára is 62 év). Cseres-Gergely (2015) tanulmánya szerint az 55-64 éves korosztályú nők csoportjában 1999 és 2006 között 5-7,4\%-al nőtt a 
foglalkoztatási arány. Az érintett korcsoportban a kényszerü munkavállalás és ezzel párhuzamosan a gyermekek családalapítása együttesen stresszként hathat a nőkre, ami nagyobb valószínüséggel vezethet pszichoszomatikus tünetek megjelenéséhez.

A vizsgálat erőssége a relatív nagy elemszám, a korcsoportok figyelembevétele, a többtényezős statisztikai elemzés és az azonos módszertan miatt az összehasonlíthatóság a 2003-2006 között vizsgált leányok eredményeivel. A vizsgálat limitációjaként említhető meg, hogy nem történt adatgyüjtés a vizsgált személyek szocio-ökonómiai státuszára, demográfiai adataira, kórtörténetre (alapbetegségek, rendszeresen szedett gyógyszerek, balesetek), az önértékelés mutatóira, táplálkozási szokásaira vonatkozóan. A jövőben a témában születő vizsgálati protokoll részeként a szocio-ökonómiai státuszra, a demográfiai adatokra, táplálkozási szokásokra, önértékelésre és anamnézisre vonatkozó adatgyüjtést javasoljuk.

\section{Összefoglalás}

A felnőtt nők körében végzett vizsgálat eredményei szerint a testi tüneteket (fejfájást, hasfájást és szédülést) átélő nők gyakorisága a (fejfájást kivéve) a 21-25 éves korcsoportban a legnagyobb, az ezt követő korcsoportokban a fejfájást és szédülést gyakran átélő nők gyakorisága váltakozó tendenciát mutat, és az 56-60 éves korosztályban mutat ismét kiugróan magas értéket, a hasfájást gyakran átélő nők gyakorisági értékei a 21-25 éves korosztályt követően csökkenést mutatnak, csak időskorban emelkednek meg újra. A pszichés tüneteket (idegesség, ingerlékenység, rosszkedvűség) gyakran tapasztaló nők gyakorisági értékei a rosszkedvüség tünetét kivéve szintén a 21-25 éves korcsoportban érik el maximális értéküket, és az idősebb korcsoportokban szintén váltakozó tendenciát követve végül az 56-60 éves korcsoportban érnek el egy - a 21-25 éves korcsoporthoz képest - kisebb csúcspontot, és ismét időskorban emelkednek meg újra. Az alvási nehézségeket (fáradtan ébredés elegendő mennyiségü alvást követően, elalvási nehézség, gyakori éjszakai felébredés) gyakran átélő nők gyakorisági értékei egymástól eltérő gyakorisági mintázatot mutatnak. A fáradtan ébredés tünetét gyakran átélő nők gyakorisági értékei gyermekkortól kezdve növekszenek, a maximális értéke a 18-20 éves korcsoportban azonosítható. Az elalvási nehézséget gyakran átélő nők gyakorisági értékeiben két csúcsérték azonosítható, az egyik a 31-35 évesek korcsoportjában, a másik a 61-65 évesek korcsoportjában. A gyakori éjszakai felébredést gyakran tapasztaló nők gyakorisági értékei az 59,5\%-os gyakoriságig növekednek, maximális értékét a tünet gyakorisága a 61-65 évesek korcsoportjában éri el.

A logisztikus regresszió eredményei alapján megállapítottuk, hogy a létrehozott pszichés és alvási nehézségek tünetcsoport esetén a bevont magyarázó változók megfelelően prediktálták a tünetcsoportok előfordulási gyakoriságát. A pszichés tünetcsoport gyakoriságát az életkor elörehaladása csökkentette, az alvási tünetcsoport és testi tünetcsoport gyakori átélése pedig növelte. Az alvási nehézség tünetcsoport gyakoriságát a menopauzális státusz és pszichés tünetcsoport átélése befolyásolta. A postmenopauzális státusz és a pszichés tünetcsoport átélése növelte az alvási nehézségek gyakoriságát. A testi tünetcsoporttal az ajánlott mértékủ fizikai aktivitást meghaladó fizikai aktivitás és a pszichés tünetcsoport átélése mutatott szoros kapcsolatot. A túlzott mértékủ fizikai aktivitás és a pszichés tünetcsoport gyakori átélése növelte a testi tünetcsoport gyakoriságát. 


\section{Irodalom}

Aro, H., Paronen, O., Aro, S. (1987): Psychosomatic symptoms among 14-16 year old Finnish adolescents. Social Psychiatry, 22(3): 171-176. DOI: https://doi.org/10.1007/BF00583852

Bardel, A., Wallander, M. A., Wedel, H., Svärdsudd, K. (2009): Age-specific symptom prevalence in women 35-64 years old: a population-based study. BMC Public Health, 9(1): 37. DOI: https://doi.org/10.1186/1471-2458-9-37

Brill, S.R., Patel, D.R., MacDonald, E. (2001): Psychosomatic disorders in pediatrics. Indian J.ournal of Pediatrics, 68(7): 597-603. DOI: https://doi.org/10.1007/BF02752270

Bodzsár, É., Zsákai, A. (2012): Magyar gyermekek és serdülök testfejlettségi állapota. Országos Növekedésvizsgálat 2003-2006. Body developmental status of Hungarian children and adolescents. Hungarian National Growth Study 2003-2006. Plantin Kiadó, Budapest.

Cseres-Gergely, Zs. (2015): A 2000-es évek magyarországi nyugdíjkorhatár-emeléseinek azonnali hatása az érintett nők munkavállalására. Közgazdasági Szemle, 62: 652-673.

Eminson, D.M. (2007): Medically unexplained symptoms in children and adolescents. Clinical Psychology Review, 27(7): 855-871. DOI: https://doi.org/10.1016/j.cpr.2007.07.007

Fehér, P., Annár, D., Zsákai, A., Bodzsár, É. (2019): Pszichoszomatikus tünetek előfordulási gyakorisága 8-17 éves magyar gyermekek körében. Orvosi Hetilap, 160(12): 464-472. DOI: https://doi.org/10.1556/650.2019.31366

Gharaibeh, M., Al-Obeisat, S., Hattab, J. (2010): Severity of menopausal symptoms of Jordanian women. Climacteric, 13(4): 385-394. DOI: https://doi.org/10.3109/13697130903050009

Haugland, S., Wold, B., Stevenson, J.I.M., Aaroe, L.E., Woynarowska, B. (2001): Subjective health complaints in adolescence: A cross-national comparison of prevalence and dimensionality. European Journal of Public Health, 11(1): 4-10. DOI: 10.1093/eurpub/11.1.4

Hjern, A., Alfven, G., Östberg, V. (2008): School stressors, psychological complaints and psychosomatic pain. Acta Paediatrica, 97(1): 112-117. DOI: https://doi.org/10.1111/j.16512227.2007.00585.x

Kinnunen, P., Laukkanen, E., Kylma, J. (2010). Associations between psychosomatic symptoms in adolescence and mental health symptoms in early adulthood. International Journal of Nursing Practice, 16(1): 43-50. DOI: https://doi.org/10.1111/j.1440-172X.2009.01782.x

Központi Statisztikai Hivatal (2019): Statisztikai tükör. Oktatási adatok, 2018/2019.

Moilanen, J., Aalto, A.M., Hemminki, E., Aro, A.R., Raitanen, J., Luoto, R. (2010): Prevalence of menopause symptoms and their association with lifestyle among Finnish middle-aged women. Maturitas, 67(4): 368-374. DOI: https://doi.org/10.1016/j.maturitas.2010.08.007

Monostori, J., Öri, P., Spéder, Zs. (2015, Szerk.): Demográfiai portré 2015. KSH NKI, Budapest. pp. 41-56.

Pikó, B., Barabás, K., Boda, K. (1997): Frequency of common psychosomatic symptoms and its influence on self-perceived health in a Hungarian student population. European Journal of Public Health, 7(3): 243-247. DOI: https://doi.org/10.1093/eurpub/7.3.243

Santalahti, P., Aromaa, M., Sourander, A., Helenius, H., Piha, J. (2005): Have there been changes in children's psychosomatic symptoms? A 10-year comparison from Finland. Pediatrics, 115(4): 434-442. DOI: https://doi.org/10.1542/peds.2004-1261

Schlarb, A.A., Claßen, M., Hellmann, S.M., Vögele, C., Gulewitsch, M.D. (2017). Sleep and somatic complaints in university students. Journal of Pain Research, 10: 1189. DOI: https://doi.org/10.2147/JPR.S125421

Zsákai, A., Karkus, Zs., Utczás, K., Biri, B., Sievert, L.L., Bodzsár, É.B. (2016): Body fatness and endogenous sexual hormones in the menopausal transition. Maturitas, 87: 18-26. DOI: https://doi.org/10.1016/j.maturitas.2016.02.006

Zsákai, A., Mascie-Taylor, N., Bodzsár, É.B. (2015): Relationship between some indicators of reproductive history, body fatness and the menopausal transition in Hungarian women. Journal of Physiological Anthropology, 34: 35-42. DOI: https://doi.org/10.1186/s40101-015-0076-0 
Levelezési cím:

Mailing address:
Fehér Piroska

Embertani Tanszék

Eötvös Loránd Tudományegyetem

Pázmány P. s. 1/c

H-1117 Budapest

Hungary

feh.pir@gmail.com 
